\title{
“FORGET HISTORY. FORGET WHAT YOU'VE SEEN BEFORE. FORGET WHAT YOU THINK YOU KNOW": RE/ESTABLISHING SPACE FOR PEOPLE OF COLOR IN OTTO BATHURST'S ROBIN HOOD
}

\author{
Sabina Rahman \\ Macquarie University
}

Medievalism can be defined as the ways in which the medieval has been represented in postmedieval eras, essentially comprising any post-medieval effort to re-imagine the Middle Ages for contemporary societies. ${ }^{1}$ David Matthews argues that Robin Hood is an exemplary figure in this field, despite the "absence of canonical literary or historical texts." 2 The Robin Hood tradition, in fact, resists any formation of a hierarchical canon, which has led Stephen Knight to provide the model of a rhizomatic structure to approach the tradition, where "the coherent determinants of time, place, class and power, as well as their servants in terms of literary tradition, operate only in a casual, not causal, way." 3 The popularity of this cultural myth, and Robin Hood's screen presence, has contributed to this dynamic, rhizomatic character that is more firmly established in his post-medieval afterlife than in his medieval origins.

From the first feature film about the hero in 1908, Robin Hood has been the subject of a motion picture at least once a decade, and the subject of a television show every decade since the 1950s. The content and endurance of these medievalist narratives reveal more about contemporary society and experience than they do about medieval England, and they form part of the transtemporal framework of popular medievalism, where there is a co-existence of the past and present, for the discussion of contemporary anxieties. ${ }^{4}$ Discussions about medievalism have in recent years considered racial tensions that are evident within the texts. Tison Pugh and Lynn Ramey's edited collection Race, Class, and Gender in "Medieval" Cinema closely examines the social and political ideologies contained in medievalist films and exposes structural issues around racism in contemporary society through an engagement with the medieval. ${ }^{5}$ Cord Whitaker and Helen Young have extended those discussions to examine the argument of historical accuracy and its ability to deny people of color access into an imagined medievalist past. ${ }^{6}$

\footnotetext{
${ }^{1}$ See Tom Shippey, "Medievalisms and Why They Matter," in Studies in Medievalism XVII: Defining Medievalism(s), ed. Karl Fugelso (Cambridge: D. S. Brewer, 2009), 45-54.

${ }^{2}$ David Matthews, Medievalism: A Critical History, Medievalism VI (Woodbridge: D. S. Brewer, 2015), 179.

${ }^{3}$ Stephen Knight, Reading Robin Hood: Content, Form and Reception in the Outlaw Myth, Manchester Medieval Literature and Culture (Manchester: Manchester University Press, 2015), 237.

${ }^{4}$ See Stephanie Trigg, "Medievalism and Theories of Temporality," in The Cambridge Companion to Medievalism, ed. Louise D'Arcens, Cambridge Companions to Culture (Cambridge: Cambridge University Press, 2016), 196.

${ }^{5}$ Tison Pugh and Lynn Ramey, ed., Race, Class, and Gender in "Medieval" Cinema, The New Middle Ages (New York: Palgrave Macmillan, 2007).

${ }^{6}$ For further discussions on racist gatekeeping in medievalism, see Cord J. Whitaker, "Race-ing the Dragon: the Middle Ages, Race and Trippin' into the Future," postmedieval: A Journal of Medieval Cultural Studies 6, no. 1 (2015): 3-11; Helen Young, “'It's the Middle Ages, Yo!': Race, Neo/medievalisms, and the World of Dragon Age," This Year's Work in Medievalism 27 (2012): 2-9; Helen Young, "Race in Online Fantasy Fandom: Whiteness on Westeros.org," Continuum 28, no. 5 (2014): 737-47; and Helen Young, Race and Popular Fantasy Literature: Habits of Whiteness, Routledge Interdisciplinary Perspectives on Literature 30 (New York: Routledge, 2015).
}

Sabina Rahman, “'Forget history. Forget what you've seen before. Forget what you think you know': Re/Establishing Space for People of Color in Otto Bathurst's Robin Hood." The Bulletin of the International Association for Robin Hood Studies 2 (2019): 1-9. 
Robin Hood has largely come away unscathed within these discussions, perhaps in part due to an under-examination of the area. The release, and subsequent popular criticism, of Otto Bathurst's Robin Hood ${ }^{7}$ provides an opportunity to examine the way in which racial aspects of the Robin Hood legend have developed on screen. This article will discuss the representation of Yahya as one of the pivotal figures of agitation for social reform in Bathurst's film, tracing his ancestry from his on-screen avatars to note a significant change that is displayed in the power dynamics between Yahya and Robin. Through this examination, I will suggest that dismissing the film's commitment to diversity as "political correctness gone mad" not only fundamentally misunderstands what medievalism is and what it does, but also attempts to police black bodies in a made-up past.

In The Middle Ages in Popular Imagination, Paul Sturtevant notes that the film and television industries have been the leading influencers of historical consciousness over the last century. ${ }^{8}$ The accessibility of film, and the immediacy and intensity of reactions when watching a film, allow the viewer to "recover a context for people and incidents distant from them in space or time." ${ }^{9}$ However, the articulation and rearticulation of this period in film and television means that the Middle Ages can be manipulated for particular purposes. Sturtevant observes that connections made between "fantasies and historical reality [have] worrying implications" which include some uncomfortable racial prejudices and tensions. ${ }^{10}$ These racial tensions are fundamentally involved with discourses of medievalism. As Laurie Finke and Martin Shichman note, there is a distinctly racialized aspect to on-screen medievalism:

The first thing everybody notices (or perhaps does not even need to notice) about films set in the Middle Ages, is that the characters are usually white. The fantasy of the Middle Ages has always been the exclusive province of European colonialism, representing the historical legitimization of white, Christian, European domination. A non-white character in such a landscape would surely seem "unrealistic" and need explaining. ${ }^{11}$

The ubiquitous whiteness from the medieval Robin Hood legend had been generally maintained in Robin Hood screen texts with an assumption that the legend was the product of a culturally isolated European past. ${ }^{12}$ Robin Hood films and television programs have tended

\footnotetext{
${ }^{7}$ Robin Hood, directed by Otto Bathurst (Summit Entertainment and Lionsgate, 2018).

${ }^{8}$ Paul B. Sturtevant, The Middle Ages in Popular Imagination: Memory, Film and Medievalism, New Directions in Medieval Studies 1 (London: I. B. Tauris, 2018), 85 and 75.

${ }^{9}$ Edward Benson, "Oh What a Lovely War! Joan of Arc on Screen," in The Medieval Hero on Screen:

Representations from Beowulf to Buffy, ed. Martha W. Driver and Sid Ray (Jefferson, NC: McFarland, 2004), 217.

${ }^{10}$ Paul B. Sturtevant, “'You Don't Learn It Deliberately, But You Just Know It From What You've Seen': British Understandings of the Medieval Past Gleaned From Disney's Fairy Tales," in The Disney Middle Ages: A Fairy-Tale and Fantasy Past, ed. Tison Pugh and Susan Aronstein, The New Middle Ages (New York: Palgrave Macmillan, 2012), 93.

${ }^{11}$ Laurie A. Finke and Martin B. Shichtman, "Inner-City Chivalry in Gil Junger's Black Knight: A South Central Yankee in King Leo's Court," in Race, Class, and Gender in "Medieval” Cinema, ed. Tison Pugh and Lynn Ramey, The New Middle Ages (New York: Palgrave Macmillan, 2007), 107-21.

12 The tenuousness of this assertion is a dynamic site for exploration, with recent research arguing against the misconception that the European Middle Ages and Early Modern history occurred in a cultural vacuum. See, for example, Nashid Al-Amin, True Myth: Black Vikings of the Middle Ages (Bloomington: Trafford Publishing, 2014); Imtiaz H. Habib, Black Lives in the English Archives, 1500-1677: Imprints of the Invisible (Aldershot: Ashgate, 2008; London: Routledge, 2016); Geraldine Heng, The Invention of Race in the European Middle Ages (Cambridge: Cambridge University Press, 2018).
}

Sabina Rahman, “'Forget history. Forget what you've seen before. Forget what you think you know': Re/Establishing Space for People of Color in Otto Bathurst's Robin Hood." The Bulletin of the International Association for Robin Hood Studies 2 (2019): 1-9. 
to reflect this assumption that medieval England was completely white, while making some effort towards a racially diverse cast. The inclusion of Joseph of Cordoba in The Adventures of Robin Hood, ${ }^{13}$ Nasir the Saracen in Robin of Sherwood, ${ }^{14}$ Azeem in Robin Hood: Prince of Thieves, ${ }^{15}$ and Djaq in Robin Hood ${ }^{16}$ present people of color, but in each case, that person of color is notably foreign, displaced to England from elsewhere.

In order to examine Yahya in Bathurst's Robin Hood, it is important to briefly consider Azeem from Robin Hood: Prince of Thieves. As Tison Pugh and Lynn Ramey note, "the Middle Ages has served as a preferred setting for exploring on the silver screen some of society's deepest concerns." 17 Azeem, a black Muslim, was laden with the social anxieties and racial tensions of being black and Muslim in the direct aftermath of the first Gulf War, converging blackness and Arab/Islamic representations. Lynn Shutters notes that Muslims and Arabs tend to be portrayed poorly in Western film, typecast as "lascivious sheiks, religious fanatics, and cold-blooded terrorists, Arabs on the silver screen are caricatures, not characters." 18 Jack Shaheen argues that the vilification of Arabs on screen reveals "cinema's systematic, pervasive, and unapologetic degradation and dehumanization of a people."19 Interestingly, however, his study includes Robin Hood: Prince of Thieves is one of only a few exceptional films that represent Arab culture favorably. ${ }^{20}$ Although Azeem's presence in medieval England fulfils a narrative function, his presence also sows what Finke and Shichtman call the temporal "seeds of the modern" 21 to allow a re-imagination of complex racial relationships in a non-antagonistic manner. Critics such as John Aberth, who dismissed the film as "an excuse to push a modern, politically correct agenda, which includes multiculturalism," 22 perhaps misunderstand its aims and its value in exposing contemporary anxieties. These discussions are made clearer through a consideration of the parody film Robin Hood: Men in Tights. ${ }^{23}$ Dave Chappelle's character Ahchoo, the analogue of Morgan Freeman's Azeem, is initially encountered by Cary Elwes' Robin Hood while he is being beaten by soldiers. Ahchoo, during this beating, remarks "I hope somebody is getting a video of this." This unexpectedly cognizant moment references the videotaped assault of Rodney King, an African-American taxi driver. The tape, filmed by a witness from his nearby balcony, showed King being viciously attacked by several police officers during his arrest on March 3,

\footnotetext{
13 "The Wanderer," The Adventures of Robin Hood, directed by Bernard Knowles, ITC, April 16 1956; and "The York Treasure," The Adventures of Robin Hood, directed by Terry Bishop, ITC, April 1, 1957.

${ }^{14}$ Robin of Sherwood, created by Richard Carpenter (HTV and Goldcrest Films, 1984-1986).

${ }^{15}$ Robin Hood: Prince of Thieves, directed by Kevin Reynolds (Morgan Creek and Warner Bros., 1991).

${ }^{16}$ Robin Hood, created by created by Dominic Minghella and Foz Allan (Tiger Aspect Productions and British Broadcasting Corporation, 2006-2009).

${ }^{17}$ Tison Pugh and Lynn Ramey, "Introduction: Filming the "Other" Middle Ages," in Race, Class, and Gender in "Medieval" Cinema, ed. Tison Pugh and Lynn Ramey, The New Middle Ages (New York: Palgrave Macmillan, 2007), 1.

${ }^{18}$ Lynn Shutters, "Vikings Through the Eyes of an Arab Ethnographer: Constructions of the Other in The 13th Warrior," in Race, Class, and Gender in "Medieval" Cinema, ed. Tison Pugh and Lynn Ramey, The New Middle Ages (New York: Palgrave Macmillan, 2007), 77.

${ }^{19}$ Jack G. Shaheen, Reel Bad Arabs: How Hollywood Vilifies a People (New York: Olive Branch Press, 2001), 1.

${ }^{20}$ Shaheen, Reel Bad Arabs, 500.

${ }^{21}$ Finke and Shichtman, "Inner-City Chivalry in Gil Junger's Black Knight," 109.

${ }^{22}$ John Aberth, A Knight at the Movies: Medieval History on Film (New York: Routledge, 1993), 190.

${ }^{23}$ Robin Hood: Men in Tights, directed by Mel Brooks (Brooksfilms and Gaumont, 1993).
}

Sabina Rahman, “'Forget history. Forget what you've seen before. Forget what you think you know': Re/Establishing Space for People of Color in Otto Bathurst's Robin Hood." The Bulletin of the International Association for Robin Hood Studies 2 (2019): 1-9. 
1991. The incident triggered the Los Angeles riots in April and May 1992. ${ }^{24}$ Azeem and Achoo, rather than fulfilling a political correctness quota, reflect contemporary racial anxieties. The characters exemplify Arthur Lindley's assertion that medievalist material of this nature can be "lifted out of historical sequence to serve as [...] 'a distant mirror of the present,' an analogue or distancing device that enables us to see ourselves from a position of estrangement." 25

Bathurst's Robin Hood is an extension of this sort of self-aware tradition, for the director explicitly states that "wherever possible, the point of this Robin Hood was finally to make relevant the clichés of a story that have been blindly reinforced by a near hundred-year cinematic tradition." 26 The rearticulation of existing features in the cinematic Robin Hood corpus for contemporary audiences also necessarily connects the film with contemporary racial anxieties, which become evident from the opening monologue:

So, I would tell you what year it was, but I can't actually remember. I could bore you with the history but you wouldn't listen. What I can tell you is that this is a story about a thief. But it doesn't begin with the thief you know. He stole from the rich and gave to the poor. It became a bedtime story. But listen, forget history. Forget what you've seen before, forget what you think you know. This is no bedtime story. If stealing a few coins is all he did, all he was, Robin of Loxley, would never have become Robin Hood.

As mentioned above, historical veracity and on-screen medievalism are the source of some racial tension. Historical veracity in medievalism is often promoted for its pedagogical value, ${ }^{27}$ and is usually combined with "a belief in a recoverable truth about the past." ${ }^{28}$ However, the pastness that is represented in medievalism lends itself to the exclusion of others based on race, class or gender. ${ }^{29}$ Bathurst's directive to "forget history," therefore, explicitly positions his film against that exclusionary model of medievalism which uses the argument of historical veracity to deny people of color access to these imagined medieval spaces.

The effect of this is tangible. Although Yahya's presence in the narrative still necessitates some explanation, his presence in medieval England does not. His presence in the town and his interactions with other people do not mark him as different. There are no hints of the "painted man" comments that Azeem from Robin Hood: Prince of Thieves was subjected to. He is entirely normalized in the town, no one giving him a second glance because, crucially, there are other people of color in this film. Even during the battle scenes in the Crusades, a person of color is in Robin's company, his allegiances made clear by his uniform and British accent, and not his skin color. By rejecting history, and engaging in the practice of color-blind

\footnotetext{
${ }^{24}$ See Rebecca Rissman, Rodney King and the L.A. Riots (Minneapolis: ABDO Publishing Company, 2014).

${ }^{25}$ Arthur Lindley, "Once, Present, and Future Kings: Kingdom of Heaven and the Multitemporality of Medieval Film" in Race, Class, and Gender in "Medieval" Cinema, ed. Tison Pugh and Lynn Ramey, The New Middle Ages (New York: Palgrave Macmillan, 2007), 20.

${ }^{26}$ Otto Bathurst, as quoted by Kevin Maher, "No Tights Allowed: Meet the 21st-Century Robin Hoodie," The Times, November 17, 2018, 4-5.

${ }^{27}$ See Benson, "Oh What a Lovely War! Joan of Arc on Screen," 217-37; and Robert A. Rosenstone, "The Reel Joan of Arc: Reflections on the Theory and Practice of the Historical Film," The Public Historian 25, no. 3 (2003): 61-77.

${ }^{28}$ Bettina Bildhauer, Filming the Middle Ages (London: Reaktion Books, 2011), 227.

${ }^{29}$ See Lynn Ramey, "In Praise of Troubadourism: Creating Community in Occupied France 1942-43," in Race, Class, and Gender in "Medieval” Cinema, ed. Tison Pugh and Lynn Ramey, The New Middle Ages (New York: Palgrave Macmillan, 2007), 139-54.
}

Sabina Rahman, “'Forget history. Forget what you've seen before. Forget what you think you know': Re/Establishing Space for People of Color in Otto Bathurst's Robin Hood." The Bulletin of the International Association for Robin Hood Studies 2 (2019): 1-9. 
casting, ${ }^{30}$ Bathurst's film contributes to a larger conversation. Mary Beltrán suggests that representations of people of color in film and television, both as individuals and as groups, form an important contribution to the social imaginary about race by challenging essentialist notions about race. ${ }^{31}$ The representation of dynamic and fluid racial identities on screen challenges the notion of the fixedness of race and racial identities. Yahya's presence, therefore, engages with these changing discourses of black visibility through and within a landscape that is not entirely white.

George Lipsitz suggests that diversity of representation can mediate established historical identities by representing past identities but "changing [their] meanings in the present." 32 Yahya's character becomes particularly noteworthy in this context. Although Kris Swank characterizes Yahya as the "junior partner" to Robin's "white savior" due to his losing his hand, and suggests that it "[rendered] him effectively castrated and impotent," ${ }^{3}$ Yahya's ability to maintain power in his relationship with Robin indicates that this is not the case. Despite appearing to fulfil a similar sidekick function to that of Azeem, he is not indebted to Robin. His presence in England is not due to any obligation, but rather due to his own political agenda. He has a cause, and he recruits Robin, saying "this war, all wars, and everything happening here is as old as time. Rich men getting richer. Men of power taking more power from the blood of innocents. Yours. Mine. And my son's. And I want to stop it. But I cannot do it alone." The Robin Hood tradition is characterized by a loss of faith in the intentions or abilities of people in positions of authority, but Bathurst's Robin admits that he only played the part of The Hood to win Marian back, not to aid the oppressed. When Robin was fighting in the Crusades, he says all he ever "thought about was coming back here and being with [Marian]. Sitting in our manor, eating and drinking and not doing very much." Robin of Locksley only became Robin Hood because of Yahya. Where Azeem walked behind Robin in Robin Hood: Prince of Thieves, saying "it seems safer to appear to be your slave rather than your equal," Yahya, who uses the same nickname for Robin that Azeem had, says "follow me, English." He walks in front and Robin follows. In Bathurst's film, far from being the white savior, Robin Hood becomes Yahya's lost hand.

Tison Pugh and Angela Jane Weisl state that part of the allure of Robin Hood lies with the possibility, slight though it may be, that he was a real man. ${ }^{34}$ However, it is in the mythic qualities of the Robin Hood tradition, the ability to create a past in which a reimagination of contemporary anxieties can be played out in a medievalist setting, that the true value lies. As Stephen Knight notes, these texts offer "views on what narratives and forms of representation have been popular at any given time; the patterns to be found in them all feed out of their

\footnotetext{
${ }^{30}$ Where casting decisions are made without consideration of the actor's ethnicity or skin color.

${ }^{31}$ Mary Beltrán, "Latina/os On TV!: A Proud (and Ongoing) Struggle Over Representation and Authorship," in The Routledge Companion to Latina/o Popular Culture, ed. Frederick Luis Aldama (New York: Routledge, 2016), 23-33.

${ }^{32}$ George Lipsitz, "The Historical Study of Popular Culture," in A Companion to Popular Culture, ed. Gary Burns, Blackwell Companions in Cultural Studies 38 (Malden, MA: Wiley Blackwell, 2016), 25.

${ }^{33}$ Kris Swank, "Back in Black in Sherwood: Revisiting the Black Outlaw in Robin Hood Adaptations," Academia.edu, February 2, 2020, accessed May 31, 2020,

https://www.academia.edu/42321658/Back_in_Black_in_Sherwood_Revisiting the Black_Outlaw_in_Robin Hood Adaptations 2020/, 17.

${ }^{34}$ Tison Pugh and Angela Jane Weisl, Medievalisms: Making the Past in the Present (New York: Routledge, 2013), 65 .
}

Sabina Rahman, “'Forget history. Forget what you've seen before. Forget what you think you know': Re/Establishing Space for People of Color in Otto Bathurst's Robin Hood." The Bulletin of the International Association for Robin Hood Studies 2 (2019): 1-9. 
contexts and do not remain sequestered inside their textual confines only." 35 In these creative medievalism spaces, accuracy and authenticity are not crucial factors. As Bettina Bildhauer notes, what matters to audiences is that the world 'feels' right. ${ }^{36}$ If, as Finke and Shichman suggest, the Middle Ages has become synonymous with fantasy, ${ }^{37}$ the fantasy of Robin Hood embracing a racially diverse cast certainly feels right.

${ }^{35}$ Knight, Reading Robin Hood, 230.

${ }^{36}$ Bettina Bildhauer "Medievalism and Cinema," in The Cambridge Companion to Medievalism, ed. Louise D’Arcens, Cambridge Companions to Culture (Cambridge: Cambridge University Press, 2016), 49.

${ }^{37}$ Finke and Shichtman, "Inner-City Chivalry in Gil Junger's Black Knight," 109.

Sabina Rahman, “'Forget history. Forget what you've seen before. Forget what you think you know': Re/Establishing Space for People of Color in Otto Bathurst's Robin Hood." The Bulletin of the International Association for Robin Hood Studies 2 (2019): 1-9. 


\section{BIBLIOGRAPHY}

Aberth, John. A Knight at the Movies: Medieval Histories on Film. New York: Routledge, 1993.

Al-Amin, Nashid. True Myth: Black Vikings of the Middle Ages. Bloomington: Trafford Publishing, 2014.

Bathurst, Otto, dir. Robin Hood. Summit Entertainment and Lionsgate, 2018.

Beltrán, Mary. "Latina/os On TV!: A Proud (and Ongoing) Struggle Over Representation and Authorship." In The Routledge Companion to Latina/o Popular Culture, edited by Frederick Luis Aldama, 23-33. New York: Routledge, 2016.

Benson, Edward. "Oh What a Lovely War! Joan of Arc on Screen." In The Medieval Hero on Screen: Representations from Beowulf to Buffy, edited by Martha W. Driver and Sid Ray, 217-37. Jefferson, NC: McFarland, 2004.

Bildhauer, Bettina. Filming the Middle Ages. London: Reaktion Books, 2011.

_. "Medievalism and Cinema." In The Cambridge Companion to Medievalism, edited by Louise D'Arcens, 45-59. Cambridge Companions to Culture. Cambridge: Cambridge University Press, 2016.

Bishop, Terry, dir. "The York Treasure.” April 1, 1957. The Adventures of Robin Hood. ITC Entertainment, 1955-1959.

Brooks, Mel, dir. Robin Hood: Men in Tights. Brooksfilms and Gaumont, 1993.

Carpenter, Richard, creator. Robin of Sherwood. HTV and Goldcrest Films, 1984-1986.

Finke, Laurie A., and Martin B. Shichtman. "Inner-City Chivalry in Gil Junger's Black Knight: A South Central Yankee in King Leo's Court.” In Race, Class, and Gender in "Medieval" Cinema, edited by Tison Pugh and Lynn Ramey, 107-21. New York: Palgrave Macmillan, 2007.

Habib, Imtiaz H. Black Lives in the English Archives, 1500-1677: Imprints of the Invisible. Aldershot: Ashgate; London: Routledge, 2017.

Heng, Geraldine. The Invention of Race in the European Middle Ages. Cambridge: Cambridge University Press, 2018.

Knight, Stephen, Reading Robin Hood: Content, Form and Reception in the Outlaw Myth. Manchester Medieval Literature and Culture. Manchester: Manchester University Press, 2015.

Knowles, Bernard, dir. "The Wanderer.” April 16, 1956. The Adventures of Robin Hood. ITC Entertainment, 1955-1959.

Lindley, Arthur. "Once, Present, and Future Kings: Kingdom of Heaven and the Multitemporality of Medieval Film." In Race, Class, and Gender in "Medieval" Cinema, edited by Tison Pugh and Lynn Ramey, 15-29. The New Middle Ages. New York: Palgrave Macmillan, 2007.

Lipsitz, George, "The Historical Study of Popular Culture." In A Companion to Popular Culture, edited by Gary Burns, 13-30. Malden, MA: Wiley Blackwell, 2016.

Maher, Kevin. "No Tights Allowed: Meet the 21st-Century Robin Hoodie." The Times, November 17, 2018, 4-5.

Matthews, David, Medievalism: A Critical History. Medievalism VI. Suffolk: D. S. Brewer, 2015.

Sabina Rahman, “'Forget history. Forget what you've seen before. Forget what you think you know': Re/Establishing Space for People of Color in Otto Bathurst's Robin Hood." The Bulletin of the International Association for Robin Hood Studies 2 (2019): 1-9. 
Minghella, Dominic and Foz Allan, creators. Robin Hood, Tiger Aspect Productions and British Broadcasting Corporation, 2006-2009.

Pugh, Tison, and Lynn Ramey. "Introduction: Filming the "Other" Middle Ages." In Race, Class, and Gender in "Medieval" Cinema, edited by Tison Pugh and Lynn Ramey, 112. The New Middle Ages. New York: Palgrave Macmillan, 2007.

Pugh, Tison, and Angela Jane Weisl. Medievalisms: Making the Past in the Present. New York: Routledge, 2013.

Ramey, Lynn, "In Praise of Troubadourism: Creating Community in Occupied France 194243." In Race, Class, and Gender in "Medieval" Cinema, edited by Tison Pugh and Lynn Ramey, 139-54. The New Middle Ages. New York: Palgrave Macmillan, 2007.

Reynolds, Kevin, dir. Robin Hood: Prince of Thieves. Morgan Creek and Warner Bros., 1991.

Rissman, Rebecca. Rodney King and the L.A. Riots. North Mankato: ABDO Publishing Company, 2014.

Rosenstone, Robert A. "The Reel Joan of Arc: Reflections on the Theory and Practice of the Historical Film." The Public Historian 25, no. 3 (2003), 61-77.

Shaheen, Jack. Reel Bad Arabs: How Hollywood Vilifies a People. New York: Olive Branch Press, 2001.

Shippey, Tom. "Medievalisms and Why They Matter." In Studies in Medievalism XVII: Defining Medievalism(s), edited by Karl Fugelso, 45-54. Cambridge: D. S. Brewer, 2009 .

Shutters, Lynn. "Vikings Through the Eyes of an Arab Ethnographer: Constructions of the Other in The 13th Warrior." In Race, Class, and Gender in "Medieval" Cinema, edited by Tison Pugh and Lynn Ramey, 77-89. The New Middle Ages. New York: Palgrave Macmillan.

Sturtevant, Paul B. The Middle Ages in Popular Imagination: Memory, Film and Medievalism. New Directions in Medieval Studies 1. London: I. B. Tauris, 2018.

—_ " "You Don't Learn It Deliberately, But You Just Know It From What You've Seen': British Understandings of the Medieval Past Gleaned From Disney's Fairy Tales." In The Disney Middle Ages: A Fairy-Tale and Fantasy Past, edited by Tison Pugh and Susan Aronstein, 77-97. The New Middle Ages. New York: Palgrave Macmillan, 2012.

Swank, Kris. "Back in Black in Sherwood: Revisiting the Black Outlaw in Robin Hood Adaptations." Academia.edu, February 2, 2020, accessed May 31, 2020. https://www.academia.edu/42321658/Back in Black in Sherwood Revisiting the Black Outlaw in Robin_Hood_Adaptations_2020/, 1-22.

Trigg, Stephanie. "Medievalism and Theories of Temporality." In The Cambridge Companion to Medievalism, edited by Louise D'Arcens, 196-209. Cambridge Companions to Culture. Cambridge: Cambridge University Press, 2016.

Whitaker, Cord J. "Race-ing the Dragon: the Middle Ages, Race and Trippin' into the Future." Postmedieval: A Journal of Medieval Cultural Studies 6, no. 1 (2015): 3-11. Young, Helen, “'It's the Middle Ages, Yo!': Race, Neo/medievalisms, and the World of Dragon Age." This Year's Work in Medievalism 27 (2012): 2-9 .

_. "Race in Online Fantasy Fandom: Whiteness on Westeros.org." Continuum 28, no. 5 (2014): 737-47.

Sabina Rahman, “'Forget history. Forget what you've seen before. Forget what you think you know': $\mathrm{Re} /$ Establishing Space for People of Color in Otto Bathurst's Robin Hood." The Bulletin of the International Association for Robin Hood Studies 2 (2019): 1-9. 
- Race and Popular Fantasy Literature: Habits of Whiteness. Routledge Interdisciplinary Perspectives on Literature 30. New York: Routledge, 2015.

Sabina Rahman, “'Forget history. Forget what you've seen before. Forget what you think you know': Re/Establishing Space for People of Color in Otto Bathurst's Robin Hood." The Bulletin of the International Association for Robin Hood Studies 2 (2019): 1-9. 